\title{
A Comparative Study for the Traditional and Modern Houses in Terms of Thermal Comfort and Energy Consumption in Umm Qais city, Jordan
}

\author{
Hussain H. Alzoubi ${ }^{*}$, Amal Th. Almalkawi ${ }^{1}$ \\ ${ }^{1}$ College of Architecture and Design, Jordan University of Science and Technology, Irbid 22110, Jordan \\ * Corresponding author's e-mail: alzoubih@umich.edu
}

\begin{abstract}
This research presents a comparison study between the vernacular architecture represented by the heritage houses (Fallahy Houses) and the typical contemporary houses in Umm Qais city in the northern part of Jordan, in terms of thermal performance. It analyzes the parameters of the heritage houses to explore the impact on the human thermal comfort and energy consumption compared with the typical modern houses. The study investigates the performance of the vernacular houses and how they respond to the physical and climatic conditions. It also shows how these houses depend on passive design to control solar gains, and decrease heating and cooling loads keeping a good level of thermal comfort inside. The study compares these vernacular houses with the traditional contemporary house in Umm Qais. The selected samples from each type of houses were taken to evaluate the impact of the vernacular principles of design, building construction and materials on the thermal performance and the thermal comfort inside the houses. Computer simulation, accompanied with measuring tools and thermal cameras, was used for thermal analysis in the selected houses. Revit software was also used for this purpose to validate the results and compare it with the real field results. The results show that the passive design strategy in the vernacular houses is substantial and more effective than the techniques used in the modern houses.
\end{abstract}

Keywords: vernacular architecture, Fallahy Houses, Umm Qais, thermal comfort, design strategy

\section{INTRODUCTION}

Through examining the vernacular architecture related to environmental issues, it is clear that humans should make all their design decisions suitable for the global natural system. Accordingly, the architecture that respects the contextual considerations and deals with natural surroundings can achieve a highly health and comfortable architectural environment (Lee et al., 1996, Magliocco et al., 1999).

Vernacular architecture involves the harmonization between the buildings with their region, natural resources, climate, culture, religious and human beings. It has architectural and constructional techniques developments through several years by trial and error (Fathy, 1986).

The improved vernacular passive principles can be integrated into building design to produce more satisfactory and low energy buildings (Foruzanmehr, 2015, Wang, 2016, Keshtkaran, 2011).

On the other hand, the typical present-day architecture does not pay attention to utilize passive systems and techniques for enhancing the indoor environments (Cantin, et al., 2010, Zhai and Previtali, 2010). In residential buildings, the lack of concern to environmental design principles causes an unsatisfactory level of indoor thermal comfort (Al Zoubi, et al., 2008, Al Zoubi and Almalkawi, 2014).

The trend towards adopting modern materials without taking into consideration the thermal efficiency of these materials in terms of the indoor thermal comfort leads to many problems in the environment (Al Zoubi, et al., 2008,, Kim, 2005).

In addition, non-climatic design responsibility of building brings out an increase in their energy 
consumption (Al Zoubi, et al., 2008, Al Zoubi and Almalkawi, 2014, Al Zoubi and Al-Shboul, 2012).

Vernacular architecture in Jordan originates from various regional, social, and cultural factors. It is formed in different sites to meet the climatic conditions and topographical needs (Khammash, 1986).

Umm Qais, considered in this research, has a dry-warm climate according to its geographical locations. The vernacular architecture seems in its dwellings and harmony relationship with their surroundings and nature to attain good living conditions for their inhabitants.

Most of studies in Jordan have been done to describe the traditional dwelling types and their architectural features; however, few of them analyze the parameters of the vernacular dwellings to explore the impact on the human thermal comfort and energy consumption compared with the contemporary dwellings.

Therefore, this research aims to investigate the performance of vernacular houses in Umm Qais village, and how they respond to its physical and climatic conditions. It also shows how these houses depend on passive design to control solar gains, as well as decrease heating and cooling loads maintaining a good level of thermal comfort inside the space. The study compares these vernacular houses with the traditional present-day house in Umm Qais. It focuses only on the building construction materials, the wall thickness and the ratio of window size to the wall area.

\section{UMM QAIS}

\section{Location and history}

Umm Qais (Gadara) is a town in northern Jordan. It is located at $\left(32^{\circ} 39^{\prime} 23^{\prime \prime} \mathrm{N}, 35^{\circ} 40^{\prime} 41^{\prime \prime} \mathrm{E}\right)$ with altitude at $378 \mathrm{~m}$ above sea level (Ministry of Tourism and Antiquities, 2018). It has best view overlooking the Jordan River, Tiberias Lake, and the Golan Heights (Figure 1) (El Khouri and Omoush, 2015).

As shown in (Figure 2 and 3) Umm Qais grew up and expanded over the past decades. It has an archeological site including historical ruins and Ottoman village (Heritage venacular houses). It also has a modern part which is called the modern village, expanded from the old town, with modern houses with fully rural farms around them (Segal, 1988).

\section{Umm Qais Vernacular Village}

The ancient city of Um Qais (called Gadara during the Roman era) has been resettled by

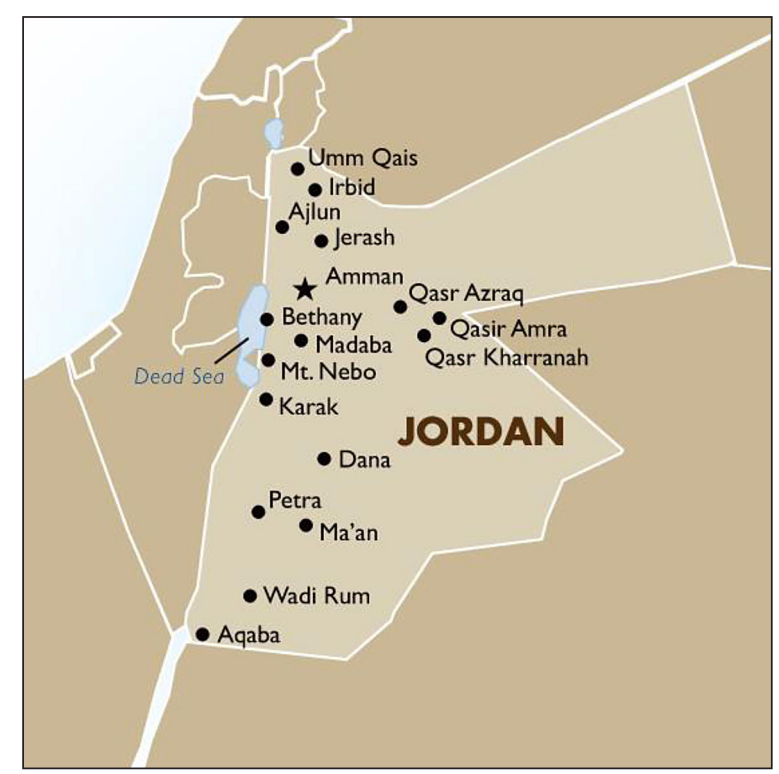

Figure 1. Map of Jordan, location of Umm Qais (https.//www.goway.com/travel-information/ africa- middle-east/jordan/introduction/)

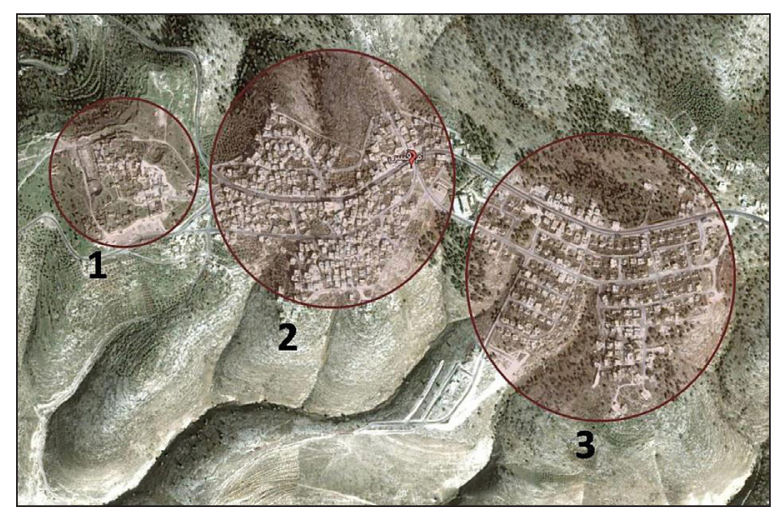

Figure 2. A Satellite image of Umm Qais village. 1. Archeological site including historical riuns and Ottoman village (Heritage venacular houses), 2. Modern village expansion, 3. Umm

Qais modern houses (Google Earth, 2018)

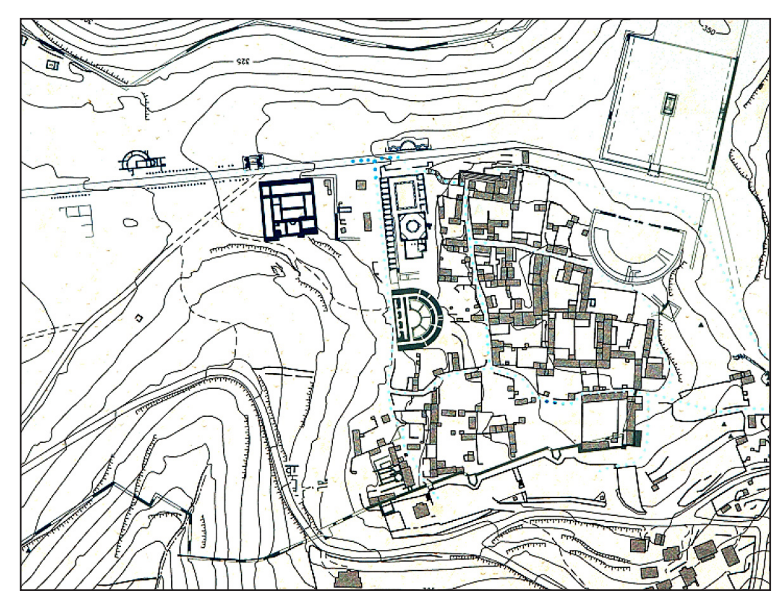

Figure 3. A map shows the Archeological site and heritage vernacular dwellings (Ministry of Tourism and Antiquities, 2018) 
inhabitants from the neighbouring villages, such as Malka and Sama Al-rousan since the $19^{\text {th }}$ century as shown in Figure 4, 5, and 6. Gadara city architecture was influenced by the Greco-Roman city; but later the city formed its own layout from local vernacular features and demands (Ministry of Tourism and Antiquities, 2018).

In 1967, the Jordanian Department of Antiquities planned to invest more in the ancient city of Gadara and extract the Greco-Roman style at the expense of the Ottoman village. Because of that the Department of Antiquities put the hand on the houses and lands in the old city pushing the inhabitants to move to a new housing project outside the ancient city. After the expropriations of houses and lands, they began archaeological excavations for the historical Roman period.

The new housing project was built in 1976 as a compensation for the people moved from their homes, see Figure 7. The project area of the housing project was about 46 hectares of the agricultural lands in the town. These new houses were very small compared to their old houses. Many large families were forced to split into different houses as a result of the inappropriate design for these families. Moreover, they had to leave numerous cultural and work traditions (e.g. keeping animals, farming and cultivating olive trees away from them). Due to these reasons, many people lost their annual wages and were obliged to search for low-paying jobs in nearby urban areas such as Irbid city (HUDC, 2018).

\section{RESEARCH METHODOLOGY}

In order to investigate the problem in the above-mentioned changes in Umm Qais in terms of the environmental conditions, selected samples from each type of dwellings, vernacular and present day, were taken to evaluate the impact of the

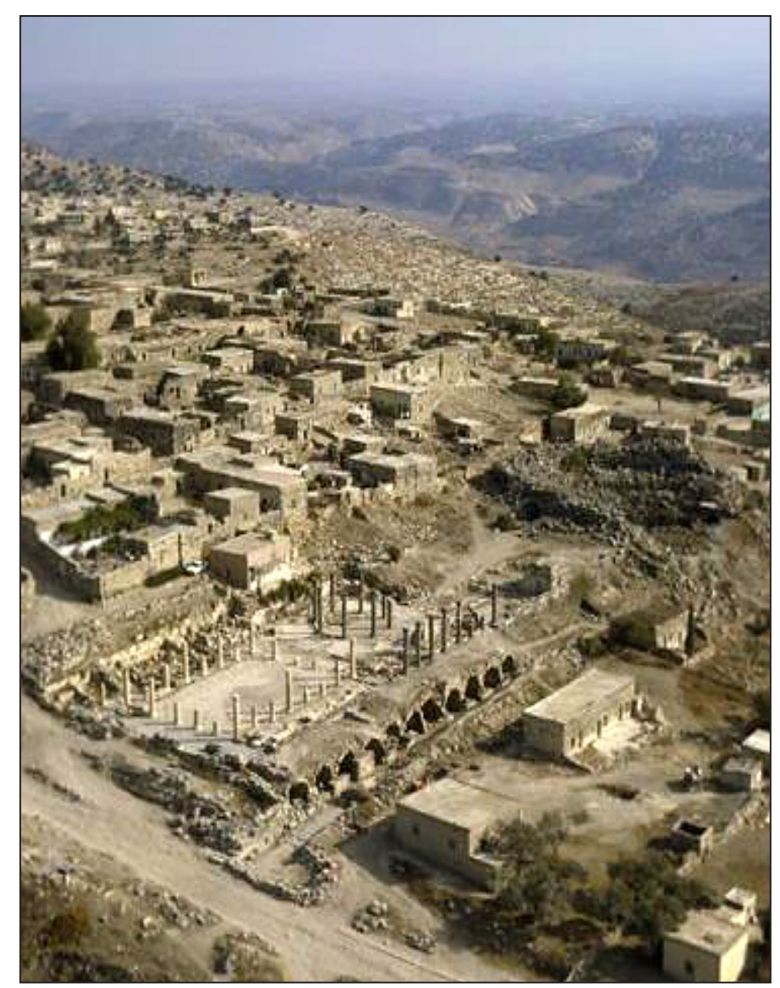

Figure 4. The heritage vernacular dwellings are on the upper part of the Greco-Roman City (https.//mapcarta.com/34604814).

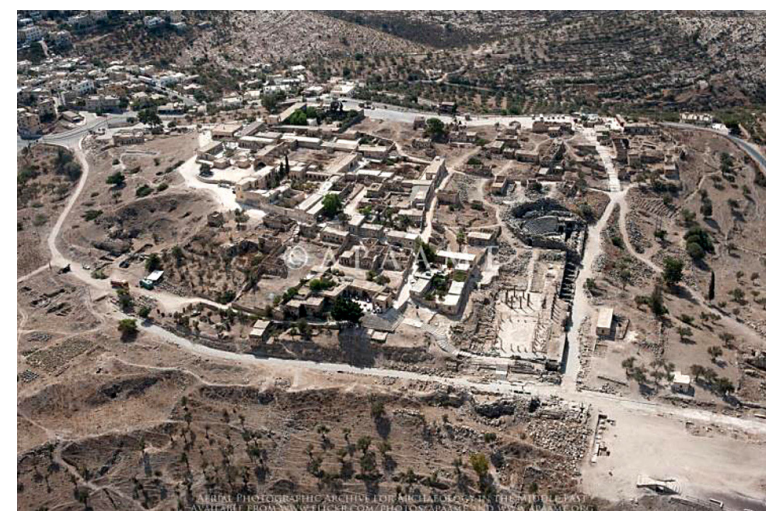

Figure 5. An Arial view shows the urban fabric of the old Umm Qais (http.//www.soniahalliday.com)

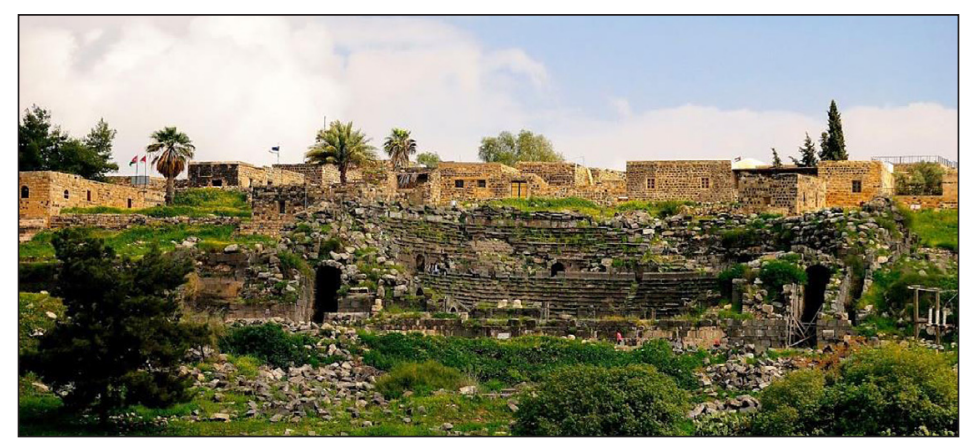

Figure 6. A different view from Roman Theatre towards the Ottoman village (the old Umm Qais) (Google earth, 2018). 2.3. Umm Qais Modern Housing 


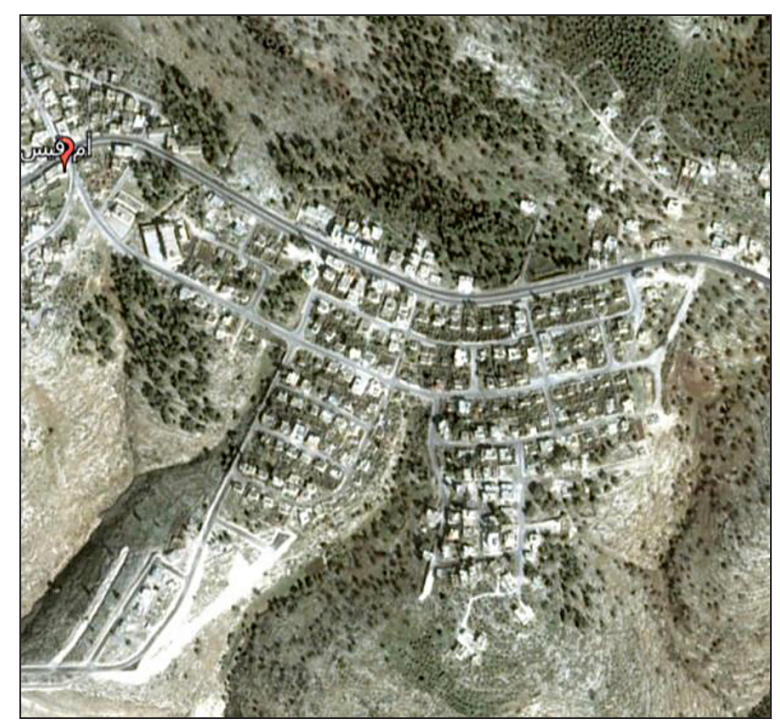

Figure 7. A satellite view of Umm Qais modern housing

vernacular principles of design, building construction, and materials on the energy analysis.

Although there have been many variables to compare between the vernacular architecture and the typical contemporary dwelling in Umm Qais city in terms of the thermal performance and the thermal comfort inside the dwellings, this research was focused only on the building typologies, building envelope including the materials, and building construction in ground floors, walls and ceilings, as well as the thickness of each layer.

\section{Umm Qais vernacular dwellings}

The two samples of vernacular dwellings under study are located in the Ottoman settlement of Umm Qais (Figures 4, 5). The first one is a triplespace dwelling and the other one is single-space dwelling (Figure 8 and 9).

The dimensions of the spaces with the thermal properties of the door used in this research are illustrated in Tables 1 and 2. In addition to the construction materials and windows of the simulated dwellings with their thermal properties are shown in Tables 3 and 4.

\section{Umm Qais typical present- day dwellings}

Umm Qais modern housing project is divided into two types of dwellings; the first one is 50 units from class A with $106 \mathrm{~m}^{2}$ in area, and the second is

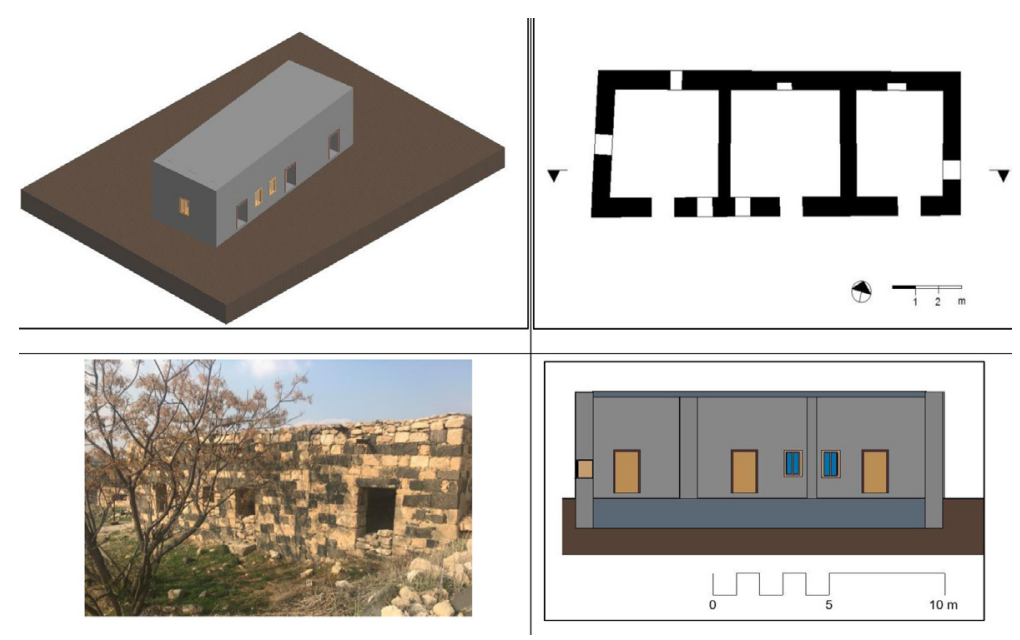

Figure 8. A triple-space dwelling. (A) 3D modeling view, (B) Plan layout, (C) External shot, and (D) Cross-section
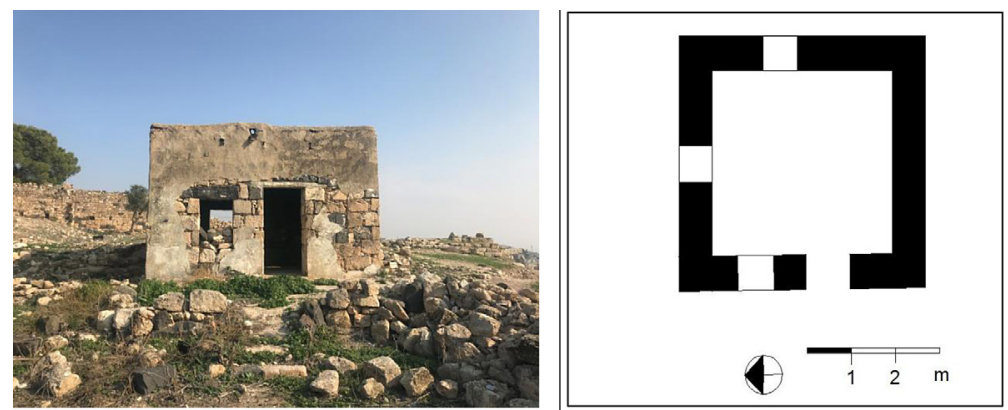

Figure 9. A single-space dwelling. (a) External shot, (b) Plan layout 
Table 1. Dimensional analysis of the vernacular dwelling under investigation

\begin{tabular}{|c|c|c|c|}
\hline \multirow{2}{*}{ Type } & Area of spaces $\left(\mathrm{m}^{2}\right)$ & Height $(\mathrm{m})$ & $\begin{array}{c}\text { Windows } \\
\text { Position- Size ratio (\%) }\end{array}$ \\
\hline \multirow{3}{*}{ Triple- space } & \multirow{2}{*}{20} & 4.7 & $\begin{array}{l}\text { SW: } 3.4 \% \\
\text { NW: } 1.8 \% \\
\end{array}$ \\
\cline { 2 - 4 } & 20 & 4.7 & SE: $3.7 \%$ \\
\cline { 2 - 4 } & 16 & 4.7 & SE: $3 \%$ \\
\hline \multirow{3}{*}{ Single-space } & \multirow{2}{*}{16} & \multirow{2}{*}{4} & NE: $2.3 \%$ \\
\cline { 2 - 4 } & & & W: $5.5 \%$ \\
\hline
\end{tabular}

Table 2. Thermal properties of the doors used in vernacular dwelling (Al Zoubi, H. et al., 2008).

\begin{tabular}{|c|c|c|c|c|}
\hline Materials & Thickness $(\mathrm{cm})$ & $\begin{array}{c}\text { Conductivity } \\
\left(\mathrm{W} / \mathrm{m}^{2} \circ \mathrm{C} / \mathrm{m}\right)\end{array}$ & $\begin{array}{c}\text { Specific heat }(\mathrm{Kcal} / \\
\mathrm{kg} \circ \mathrm{C})\end{array}$ & Density $\left(\mathrm{kg} / \mathrm{m}^{3}\right)$ \\
\hline high wood density & 5 & 0.37 & 0.13 & 1000 \\
\hline
\end{tabular}

Table 3. The material's thermal properties used in vernacular dwelling

\begin{tabular}{|c|c|c|c|c|c|c|}
\hline Type & Materials & Thickness $(\mathrm{cm})$ & $\begin{array}{c}\begin{array}{c}\text { Conductivity (W/ } \\
\left.\mathrm{m}^{2} \mathrm{C} / \mathrm{m}\right)\end{array} \\
\end{array}$ & $\begin{array}{l}\text { Specific heat } \\
\left(\text { Kcal/kg . . }{ }^{\circ}\right)\end{array}$ & Density $\left(\mathrm{kg} / \mathrm{m}^{3}\right)$ & $\begin{array}{c}\text { U-value (W/ } \\
\left.\mathrm{m}^{2} \mathrm{C}^{\circ}\right)\end{array}$ \\
\hline \multirow{4}{*}{ Wall } & Lime stone & 0.025 & 1.3 & 0.217 & 2560 & \multirow{4}{*}{1.2764} \\
\hline & Stone & 30 & 5 & 0.2 & 2480 & \\
\hline & Clay & 10 & 0.16 & 0.22 & 1600 & \\
\hline & Stone & 30 & 5 & 0.2 & 2480 & \\
\hline \multirow{5}{*}{ Ground Floor } & Earth & 99 & 1.4 & 0.215 & 1301 & \multirow{5}{*}{0.5009} \\
\hline & Gravel jeer & 45 & 0.38 & 0.235 & 1401 & \\
\hline & $\begin{array}{l}\text { Base coarse } \\
\text { stone }\end{array}$ & 10 & 1.51 & 0.231 & 2050 & \\
\hline & Sand & 45 & 0.42 & 0.239 & 1800 & \\
\hline & Cement mortar & 3 & 0.931 & 0.292 & 1850 & \\
\hline \multirow{4}{*}{ Roof } & Wood (oak) & 5 & 0.17 & 0.48 & 850 & \multirow{4}{*}{1.0188} \\
\hline & Reed & 3 & 0.056 & 0.7 & 225 & \\
\hline & Mud & 15 & 1.1 & 0.35 & 1840 & \\
\hline & Lime stone & 2 & 1.3 & 0.217 & 2560 & \\
\hline
\end{tabular}

Table 4. The vernacular dwelling window's properties

\begin{tabular}{|c|c|c|c|c|}
\hline Materials & $\begin{array}{c}\text { U-value } \\
(\mathrm{W} / \mathrm{m} 2 \circ \mathrm{C})\end{array}$ & G-value & T-sol & Specific heat $($ Kcal $/ \mathrm{kg} \circ \mathrm{C})$ \\
\hline Single glass & 5.88 & 0.636 & 0.45 & 0.2 \\
\hline
\end{tabular}

100 units from class B have $68 \mathrm{~m}^{2}$ in total area. This research took class $\mathrm{B}$ as a case study to compare them with the vernacular dwelling because the same villagers were immerged from their vernacular dwellings and resettled in this class (HUDC, 2018).

The class B dwellings have one floor that includes one living room, two bedrooms, kitchen, bathroom and one staircase. (Figure 10).

The analysis of this dwelling type is clarified in Table 5, while the materials details and their thermal features are represented in Table 6. The research assumed the type of windows and doors similar with that used in Tables 2 and 4.

\section{Building simulation}

Autodesk Revit software was used to simulate the building typology, volume and envelope including construction materials and thickness of every layer as well as the impact of these variables on the thermal performance inside spaces. This software analyzed these spaces in a building model from each type of dwellings and compared them to calculate their energy consumption (Figure 11). The simulation assumed $70 \%$ for the absorbance of each envelope layer and $87 \%$ for the emittance. It assumed that the infiltration class in each dwelling 


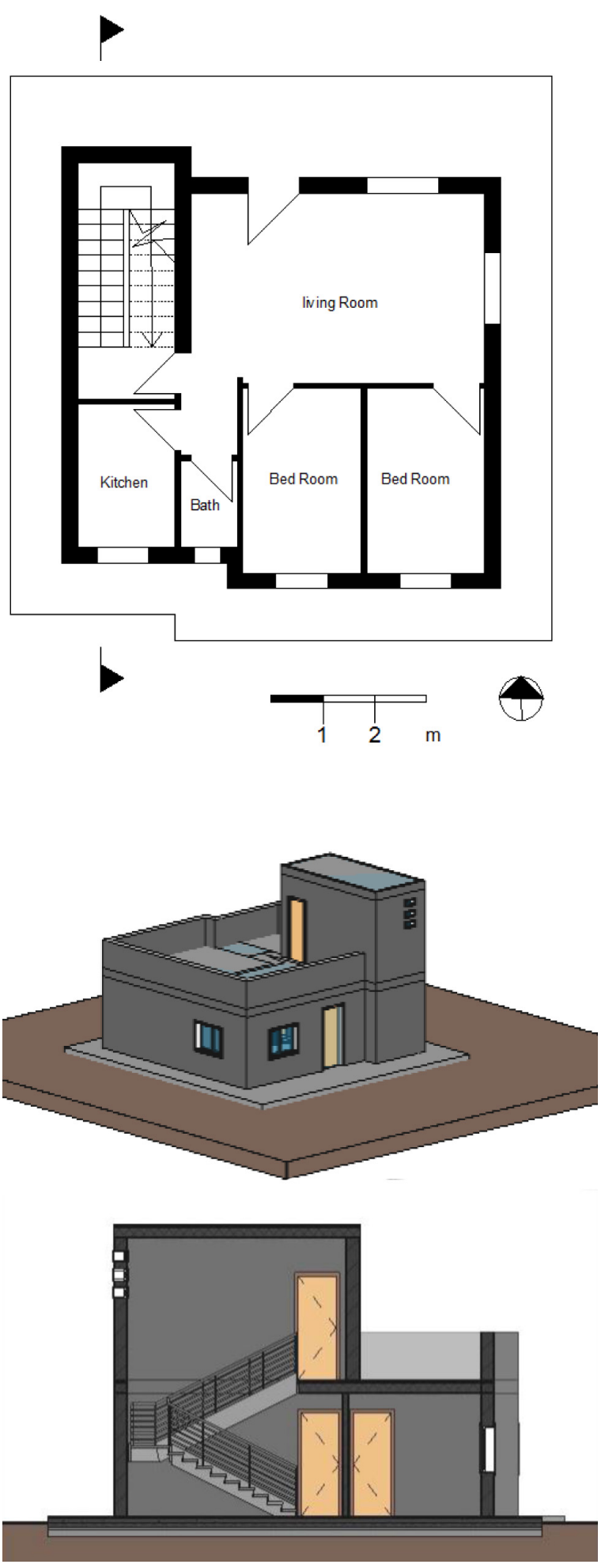

Figure 10. A present day dwelling. (A). Plan layout, (B). 3D modeling view and (C). Cross-section

is tight. The main HVAC parameters handled in this study were referenced to the ASHRAE standards.

The internal loads, the spaces appliances, the number of occupants (six persons) and the space occupancy schedules were considered as a constant in all spaces for each dwelling.
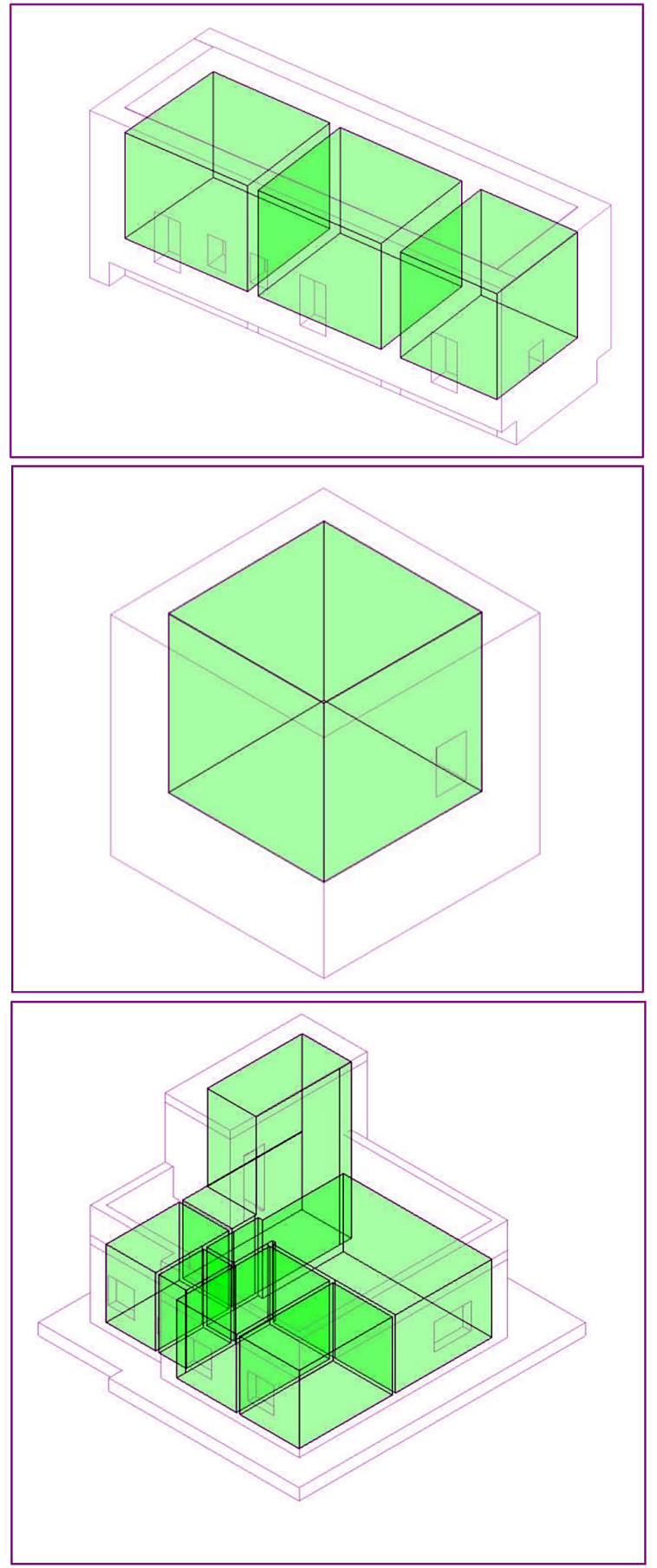

Figure 11. The internal thermal spaces analyzed by Revit software

\section{RESULTS}

The results show that the contemporary dwelling has the highest peak heating load with an amount of 9,571 (Watt), which is 50\% higher than the triple-space vernacular dwelling even though they have the same area of inside spaces, while the peak heating load of the single-space dwelling is 2,109 (Watt), see Figure 12. 
Table 5. Dimensional analysis of the present-day dwelling units in the study (HUDC, 2018).

\begin{tabular}{|c|c|c|c|c|}
\hline Type & spaces & $\begin{array}{c}\text { Area of } \\
\text { spaces }\left(\mathrm{m}^{2}\right)\end{array}$ & Height (m) & $\begin{array}{c}\text { Openings } \\
\text { position- Size ratio }\end{array}$ \\
\hline \multirow{7}{*}{$\begin{array}{l}\text { Present- day } \\
\text { dwelling }\end{array}$} & Living room & 21 & \multirow{6}{*}{2.66} & $\begin{array}{l}\text { N: } 6 \% \\
\text { E: } 9 \%\end{array}$ \\
\hline & Bed room & 8.28 & & S: $9.8 \%$ \\
\hline & Bed room & 8.28 & & S: $9.8 \%$ \\
\hline & Bath & 1.87 & & S: $5.4 \%$ \\
\hline & Kitchen & 5.31 & & S: $11.5 \%$ \\
\hline & lobby & 1.5 & & \\
\hline & Staircase & 8.74 & 5.62 & \\
\hline
\end{tabular}

Table 6. The material's thermal properties used in present-day dwelling (HUDC, 2018).

\begin{tabular}{|c|c|c|c|c|c|c|}
\hline Type & Materials & $\begin{array}{l}\text { Thickness } \\
(\mathrm{cm})\end{array}$ & $\begin{array}{l}\text { Conductivity } \\
\left(\mathrm{W} / \mathrm{m}^{2}{ }^{\circ} \mathrm{C} / \mathrm{m}\right)\end{array}$ & $\begin{array}{c}\text { Specific heat } \\
\left(\mathrm{Kcal} / \mathrm{kg}^{\circ} \mathrm{C}\right)\end{array}$ & $\begin{array}{l}\text { Density } \\
\left(\mathrm{kg} / \mathrm{m}^{3}\right)\end{array}$ & $\begin{array}{c}\text { U value } \\
\left(\mathrm{W} / \mathrm{m}^{\circ}{ }^{\circ} \mathrm{C}\right)\end{array}$ \\
\hline \multirow{3}{*}{ External wall } & Cement plaster & 2.5 & 1.3 & 0.28 & 2000 & \multirow{3}{*}{2.9535} \\
\hline & Hollow concrete block & 25 & 0.833 & 0.25 & 1300 & \\
\hline & Cement plaster & 2.5 & 1.3 & 0.28 & 2000 & \\
\hline \multirow{3}{*}{ Internal wall } & Cement plaster & 1.5 & 1.3 & 0.28 & 2000 & \multirow{3}{*}{6.987} \\
\hline & Hollow concrete block & 10 & 0.833 & 0.25 & 1300 & \\
\hline & Cement plaster & 1.5 & 1.3 & 0.28 & 2000 & \\
\hline \multirow{5}{*}{ Roof } & Cement mortar & 2.5 & 0.93 & 0.29 & 1800 & \multirow{5}{*}{4.225} \\
\hline & concrete & 3 & 1.7 & 0.24 & 2300 & \\
\hline & Asphalt-insulation & 2 & 1.2 & 0.32 & 2300 & \\
\hline & Reinforced Concrete & 20 & 1.28 & 0.26 & 2100 & \\
\hline & Cement plaster & 2.5 & 1.3 & 0.28 & 2000 & \\
\hline \multirow{7}{*}{ Ground floor } & Earth & 50 & 1.4 & 0.22 & 1300 & \multirow{7}{*}{2.0304} \\
\hline & Basecoarse stone & 15 & 1.5 & 0.23 & 2000 & \\
\hline & Asphalt-insulation & 5 & 1.2 & 0.32 & 2300 & \\
\hline & Reinforced Concrete & 10 & 1.28 & 0.26 & 2100 & \\
\hline & Sand & 9 & 0.4 & 0.24 & 1700 & \\
\hline & Cement mortar & 2.5 & 0.39 & 0.29 & 1800 & \\
\hline & Terrazzo tile & 2.5 & 1.2 & 0.24 & 2000 & \\
\hline
\end{tabular}

For cooling loads, it can be seen that the highest value is recorded at the contemporary dwelling, compared with the vernacular dwelling.

Overall, the contemporary dwelling has got a highest amount of cooling air and capacity more than the vernacular dwelling.

The results also show that the least heating load density per area was recorded at triple-space vernacular dwelling, while the heating load for the single-space dwelling is higher than the triplespace. The highest heating load density per area was recorded at the contemporary dwelling.

While comparing the cooling load per square meter, it is clear that there has been a significant difference between the present-day dwelling requirement and the vernacular dwelling. The cooling load of the present-day dwelling is three times higher than that of the triple-space vernacular dwelling. However, the cooling load of the single space vernacular dwelling is double of the cooling load per area than that of the triple-space dwelling (Figures 13 and 14)

The monthly fuel and electricity consumption for all types of dwelling was also investigated. The results show the present-day dwelling consumes more fuel and electricity than the vernacular dwellings (Figure 14).

Detailed inspection for the dwelling architectural parameters was conducted as well. The heating loads were mainly attributed walls. Most of the heat loss was through walls because the temperature in winter goes to very low degrees and the u-value for the used walls in the new dwelling units is not according to the standards (Figure 15). 
- Triple-Space Dwelling $\quad$ Single-Space Dwelling $\quad$ = Present-Day Dwelling

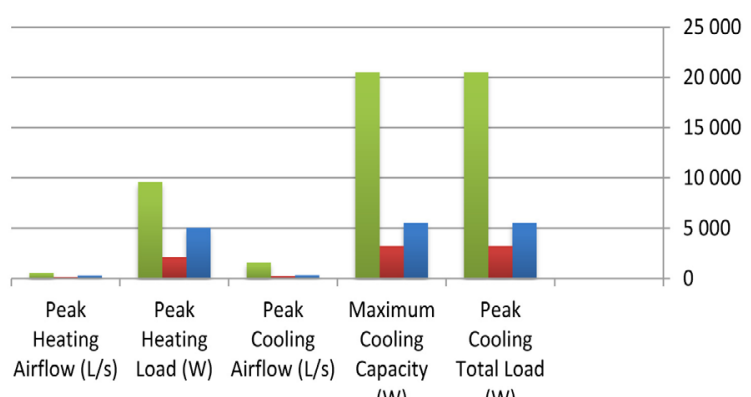

(W)

Figure 12. Peak heating and cooling load for all types of dwellings

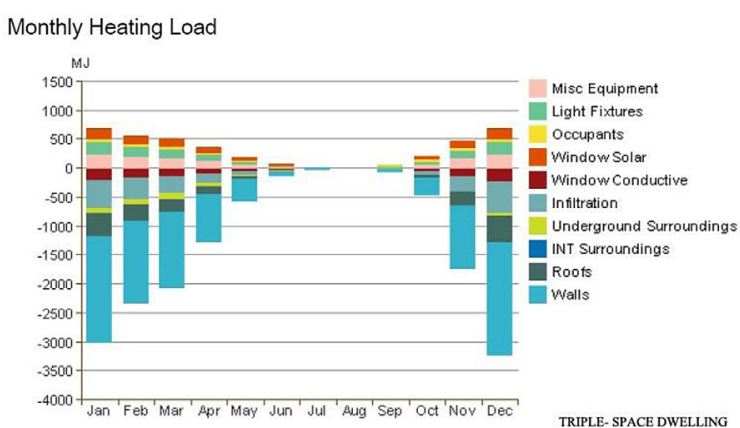

Monthly Heating Load

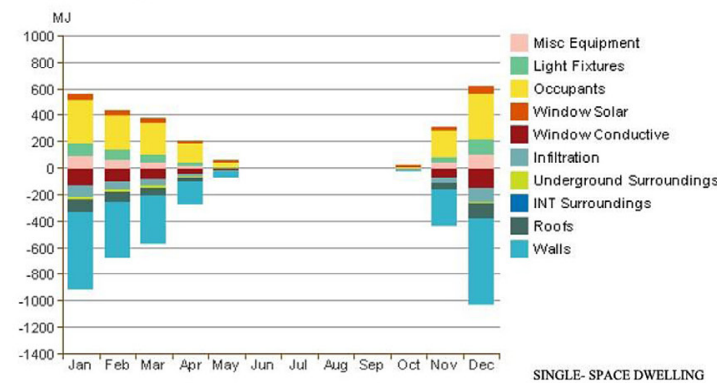

Monthly Heating Load

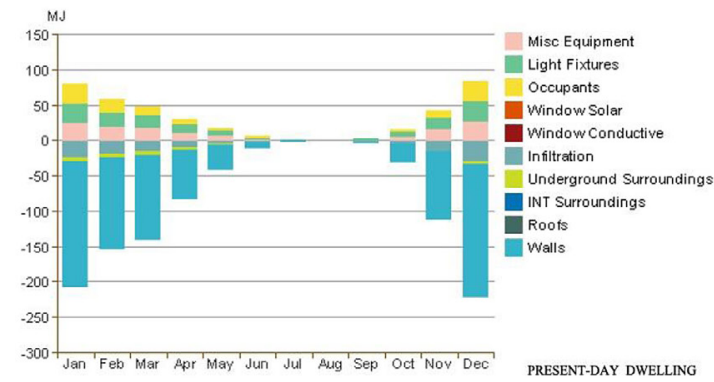

Figure 14. Monthly heating load for specific parameters for all types of dwellings

For cooling loads, also the walls carry most of the loads for many reasons; first, the area of the walls is much larger than that of any building elements, secondly, the u-value of the walls in the new dwellings does not meet the code requirements (Figure 15). However, in the
-Triple-Space Dwelling $\quad$ Single-Space Dwelling $\quad$ Present-Day Dwelling

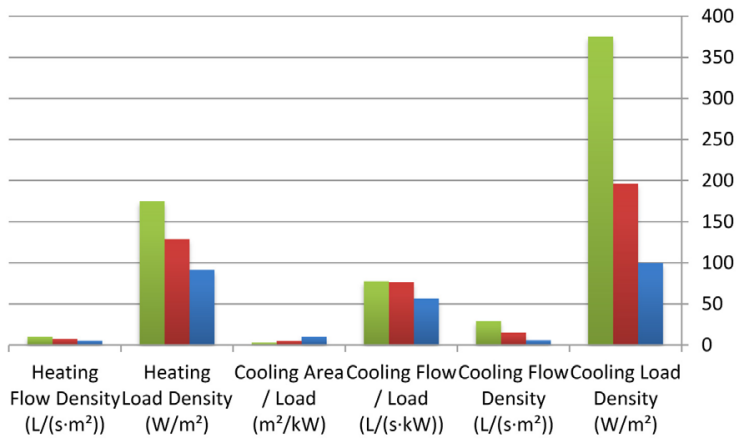

Figure 13. Heating and cooling load for all types of dwellings

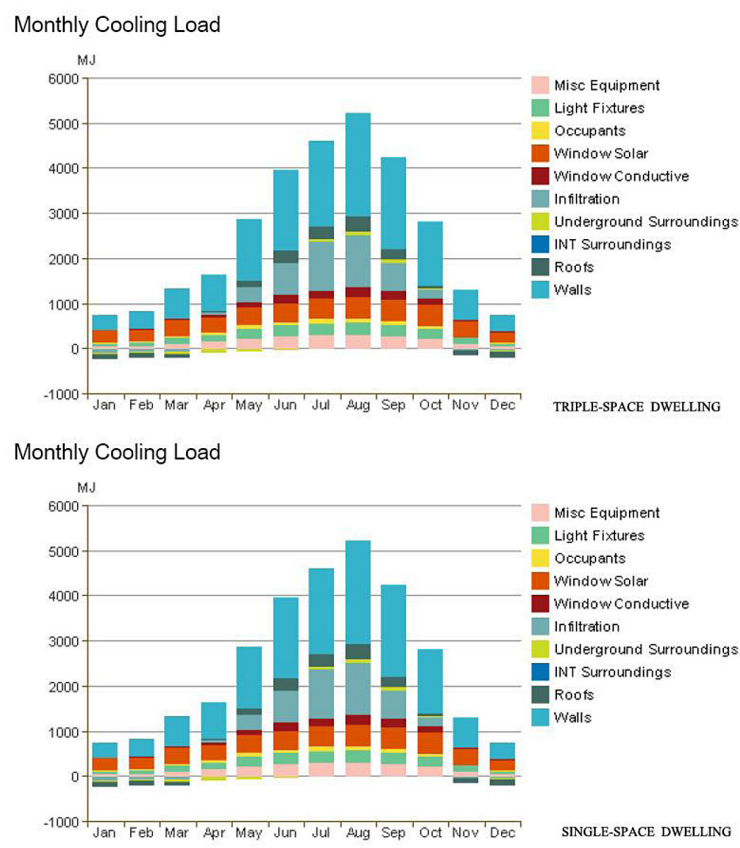

Monthly Cooling Load

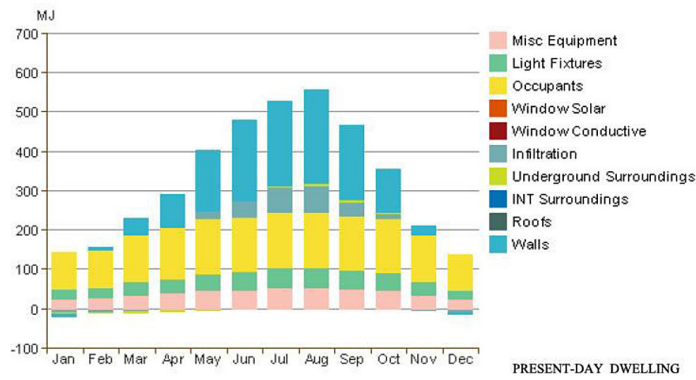

Figure 15. Monthly cooling load for specific parameters for all types of dwellings

vernacular dwellings the conditions are different; the walls are made from clay and natural stone which makes the heat loss coefficient very low and eventually leads to minimizing the heating and cooling loads. 


\section{CONCLUSIONS3}

The study investigates and compares the contemporary dwelling units with the vernacular units. It is apparent that the new project in Umm Qais city does not meet the basic principles of sustainable design in terms of material choice and others. The old vernacular housing units proved to be much better than the modern ones. This should be very clear for the architectural designers to pay attention for this important issue in building design. Designers of the modern part of Umm Qais city have not considered the building orientation either. During the field survey; it was noticed that the four directions were not an important factor in the project and there was no treatment or solution related to any of the four directions.

The window size also was not taken into consideration in the project. It is noticed that the area of window is not proportional to the area of the room, which affects the amount of energy consumption for lighting.

\section{Acknowledgements}

The authors would like to thank the municipality of Umm Qais for providing the research with the necessary maps and information. Special thanks go to the department of architecture at Jordan University of Science and Technology for using its labs to conduct the simulation.

\section{REFERENCES}

1. Al Zoubi H.H., Al-Shboul A., 2010. Low Energy Architecture and Solar Rights. Restructuring Urban Regulations, View from Jordan. Renewable Energy, 35, 333-342.

2. Al Zoubi, H. et al., 2008. Energy Efficient Design for Thermally Comforted Dwelling Units in Hot Arid Zones. Case of Vernacular Buildings in Jordan. Proceedings of the Conference on Technology \& Sustainability in the Built Environment.

3. Al Zoubi, H.H., Almalkawi, A. 2014.The Optimal Utilization of Solar Energy in Residential Buildings in Light of the Jordanian Building Regulations. Sustainable Cities and Society, 14, 441-448.

4. Cantin, R. et al., 2010. Field Assessment of Thermal Behaviour of Historical Dwellings in France. Building and Environment, 45, 473-484,
5. El Khouri, L., Omoush, M., 2015. The Abbasid Occupation at Gadara (Umm Qais), 2011 Excavation Season. Mediterranean Archaeology and Archaeometry, 15(2), 11-25.

6. Engineering, 169, 367-374.

7. Fathy, H., 1986. Natural Energy and Vernacular Architecture. Principles and Examples with Reference to hot arid climates. The University of Chicao Press, Ltd.

8. Foruzanmehr, A. 2015. People's Preception of the Ioggia. A Vernacular Passive Cooling System in Iranian Architecture. Sustainable Cities and Society, 19, 61-67.

9. Jordan Housing Urban Development Corporation (HUDC), 2018.

10. Keshtkaran, P., 2011. Harmonization between Climate and Architecture in Vernacular Heritage. A Case Study in Yazd, Iran. International Conference on Green Buildings and Sustainable Cities, 21, 428-438.

11. Khammash, A. 1986. Notes on Village Architecture in Jordan", University of Southern Louisiana.

12. Kim, D., 2005. The natural environment control system of Korean traditional architecture. Comparison with Korean Contemporar Architecture. Building and Environment, 41, 1905-1912.

13. Lee K-H., et al., 1996. Passive Design Principles and Techniques for Folk Houses in Cheju Island and UIIng Island of Korea. Energy and Buildings, 23, 207-216.

14. Magliocco A. et al. 1999. Requalification of Public Residential Buildings with Bioclimatic Approach", DIPARC Department, Faculty of Architecture of Geniva.

15. Ministry of Tourism and Antiquities (MOTA), Annual Report, Jordan, 2018.

16. Segal, A., 1988. Town Planning and Architecture in Provincia Arabia. The Cities along the Via Traiana Nova in the in the 1st-3rd centuries CE. British Archaeological Reports.

17. Wang, Y. et al. 2016. Study on the Green Design Strategies of Neo-Vernacular Architecture. Procedia Procedia Engineering, 169, 367-374.

18. Zhai Z.J., Previtali J.M., 2010. Ancient Vernacular Architecture. Characteristics Categorization and Energy Performance Evaluation. Energy and Buildings, 42, 357-367.

19. https.//www.goway.com/travel-information/ africa- middle-east/jordan/introduction/

20. https.//mapcarta.com/34604814

21. http.//www.soniahalliday.com/category-view3. php?pri=J132-2-22JT.jpg 